\title{
Performance of masonry buildings during the 20 and 27 December 2007 Bala (Ankara) earthquakes in Turkey
}

\author{
S. Adanur \\ Karadeniz Technical University, Dept. of Civil Engn., 61080, Trabzon, Turkey
}

Received: 6 September 2010 - Revised: 10 November 2010 - Accepted: 10 November 2010 - Published: 9 December 2010

\begin{abstract}
This paper evaluates the performance of masonry buildings during the 20 and 27 December 2007 Bala (Ankara) earthquakes. Bala is a township located $50 \mathrm{~km}$ southeast from Ankara city in Turkey. The majority of the buildings in the affected region are built in masonry. Most of masonry buildings were formed with random or coursed stone and mud brick walls without any reinforcement. Many of these buildings were damaged or had collapsed. The cracking and failure patterns of the buildings are examined and interpreted according to current provisions for earthquake resistance of masonry structures. The damages are due to several reasons such as poor construction quality and poor workmanship of the buildings. In addition to these reasons, the two earthquakes hit the buildings within seven days, causing progressive damage.
\end{abstract}

\section{Introduction}

Earthquake is one of the natural hazards. Turkey has been a very active seismic zone. Many destructive earthquakes occurred in Turkey up to now. Several studies have been conducted on the performances or damages of buildings during the earthquakes in Turkey (Saatcioglu and Bruneau, 1993; Bruneau, 2002; Dogangun, 2004; Arslan and Korkmaz, 2007; Bayraktar et al., 2007a, b; Inel et al., 2008). Saatcioglu and Bruneau (1993) observed the performance of structures during the 13 March 1992 Erzincan earthquake in Turkey. Bruneau (2002) described the damage of reinforced concrete, masonry, and steel structures during the 17 August 1999 Marmara earthquake in Turkey. Dogangun (2004) examined the performance of reinforced concrete buildings during the 1 May 2003 Bingöl earthquake in Turkey. Arslan and Korkmaz (2007) discussed the performance of

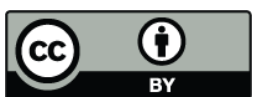

Correspondence to: S. Adanur (sadanur@ktu.edu.tr) reinforced concrete buildings during recent earthquakes in Turkey. Also observations from the earthquake damages are discussed and compared with Turkish Earthquake Code and Turkish Building Code requirements. Bayraktar et al. (2007a) investigated the performance of masonry stone buildings during the 25 and 28 March 2004 Akale (Erzurum) earthquakes in Turkey. Bayraktar et al. (2007b) investigated the behaviour of masonry buildings during the 2 July 2004 Doğubayazit (Ağri) earthquake in Turkey. Inel et al. (2008) evaluated seismic performance of regular and irregular reinforced concrete building in Turkey.

The 20 and 27 December 2007 Bala (Ankara) earthquakes damaged many masonry buildings in Bala Township and its villages. In order to understand the behaviour of these masonry buildings and to observe their performance during the earthquakes, the affected region was visited. The majority of the building stock in these villages is of masonry. The observations and assessments are presented below. Different from previous studies, the behaviour of mixed masonry buildings with walls made of masonry materials like stones and mud bricks or stones and bricks or stones and briquette, and slender structures like minaret during the earthquakes are evaluated as well in this study.

\section{Seismological aspects}

A moderate earthquake, measuring 5.6 on the Richter scale, hit the township Bala of the southeastern province of Ankara, Turkey at 11:48 LT on Thursday, 20 December 2007. Just seven days later, a second moderate earthquake of 5.5 on the Richter scale struck the same province on Thursday, 27 December 2007 at 01:48 LT.

Bala earthquakes are closely related to the tectonic deformation of the region controlled by the collision of the Arabian and Eurasian Plates. The Anatolian block is bounded by the North Anatolian and East Anatolian Faults (Fig. 1). 


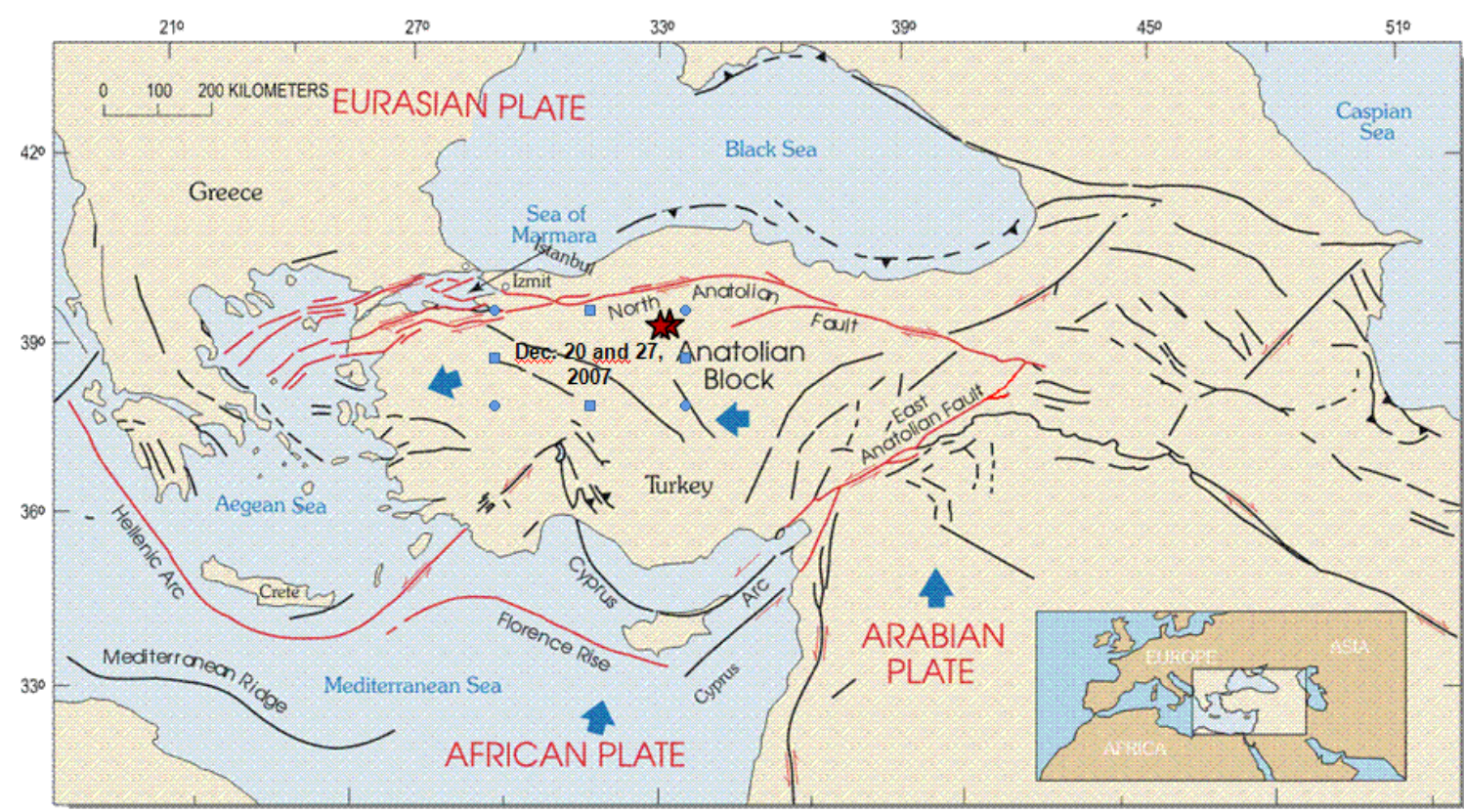

Fig. 1. Simplified tectonic map of Turkey (modified from USGS, 2008).

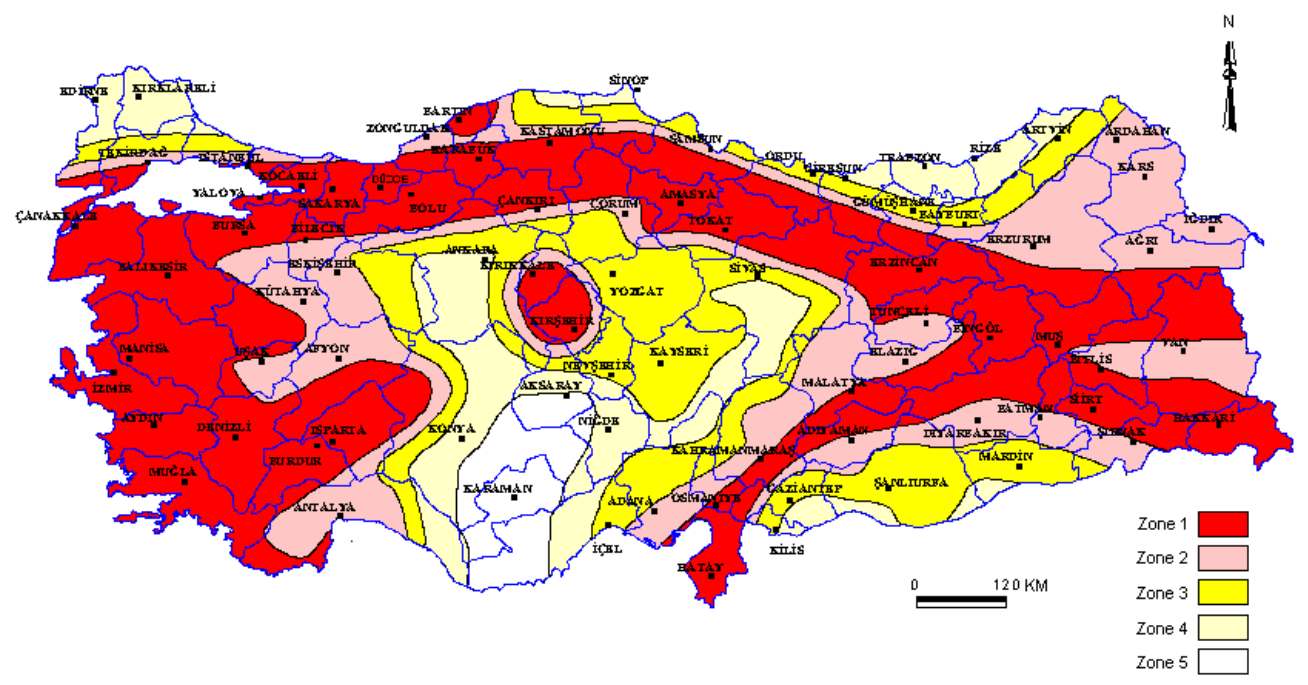

Fig. 2. Seismic zoning map of Turkey (http://www.deprem.gov.tr, 2008).

The Ministry of Public Works and Settlement of Turkey published a Seismic Zoning Map of Turkey in 1996 based on maximum acceleration. The whole country is divided into the 5 zones, as shown in Fig. 2. Ankara city is at the fourth degree earthquake zone in accordance with this map. $8 \%$ of the surface area of Ankara province is in the first degree hazard zone, $21 \%$ in the second degree hazard zone, $32 \%$ in the third degree hazard zone and $38 \%$ in the fourth degree hazard zone.
There have been no historical or instrumental records of powerful earthquakes in the vicinity of Ankara as shown in Fig. 3. There are several faults namely Tuzgölü Fault, Ezinepazari Fault, Eskiehir Fault, Keskin Fault and Gerede Fault; which can produce earthquakes in Ankara (Özmen and Kocaefe, 1999).

The parameters and the three components of the ground acceleration records and response spectrums of the Bala (Ankara) earthquakes taken at ANA01 station are given in Table 1 and Figs. 4-7, respectively. Peak ground accelerations of the three components vary between 0.4592 and $1.3574 \mathrm{~cm} \mathrm{~s}^{-2}$ (http://angora.deprem.gov.tr/rapor/bala. htm, 2008). 


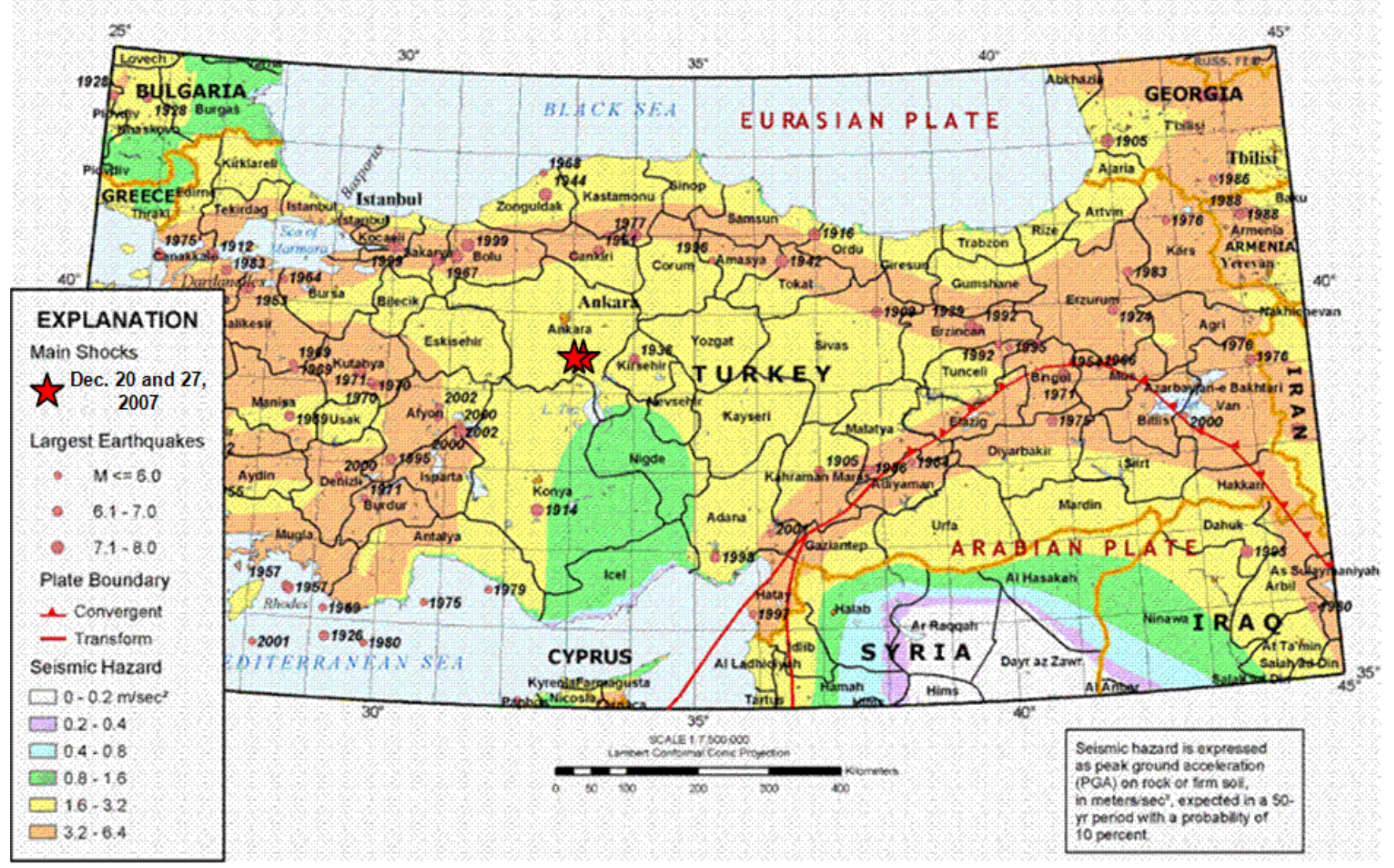

Fig. 3. Seismic hazard settings of Turkey (modified from USGS, 2008).

Table 1. Parameters of Bala (Ankara) Earthquakes (http://angora.deprem.gov.tr/rapor/bala.htm, 2008).

\begin{tabular}{llllllllll}
\hline Station Name & Date & Time & $\begin{array}{l}\text { Depth } \\
(\mathrm{km})\end{array}$ & $\begin{array}{l}\mathrm{N}-\mathrm{S} \\
\left(\mathrm{cm} \mathrm{s}^{-2}\right)\end{array}$ & $\begin{array}{l}\mathrm{E}-\mathrm{W} \\
\left(\mathrm{cm} \mathrm{s}^{-2}\right)\end{array}$ & $\begin{array}{l}\text { U-D } \\
\left(\mathrm{cm} \mathrm{s}^{-2}\right)\end{array}$ & $\begin{array}{l}\text { Latitude } \\
(\mathrm{N})\end{array}$ & $\begin{array}{l}\text { Longitude } \\
(\mathrm{E})\end{array}$ & $\begin{array}{l}\text { Region } \\
\text { ANA01 }\end{array}$ \\
\hline ANA01 & 20 December 2007 & $11: 48: 27$ & 02.8 & 0.9652 & 1.0659 & 0.4592 & 39.417 & 33.040 & Bala \\
\hline
\end{tabular}

\section{Structural behaviours}

Non-reinforced masonry structures are among the most vulnerable type of buildings during an earthquake. They are normally designed for vertical loads and, as masonry has adequate compressive strength, the structures behave well as long as the loads are vertical. When such a masonry structure is subjected to lateral inertial loads during an earthquake, the walls develop shear and flexural stresses. The strength of masonry under these conditions often depends on the bond between stone and mortar (or brick and mortar). This bond is often very poor when lime mortars or mud mortars are used. A masonry wall can also undergo in-plane shear stresses if the inertial forces are in the plane of the wall. Shear failure in the form of diagonal cracks is observed due to in-plane shear stresses. However, catastrophic collapses occur when the wall experiences out-of-plane flexure.

\section{Characteristics of masonry buildings in affected area}

According to the post earthquake building damage survey of the Turkish Ministry of Public Works and Settlement, a total of 945 buildings were heavily damaged/collapsed, 7 buildings had medium damage, 1262 buildings had low damage and 804 buildings were undamaged in Bala County and its villages during the 20 and 27 December 2007 Bala earthquakes. 

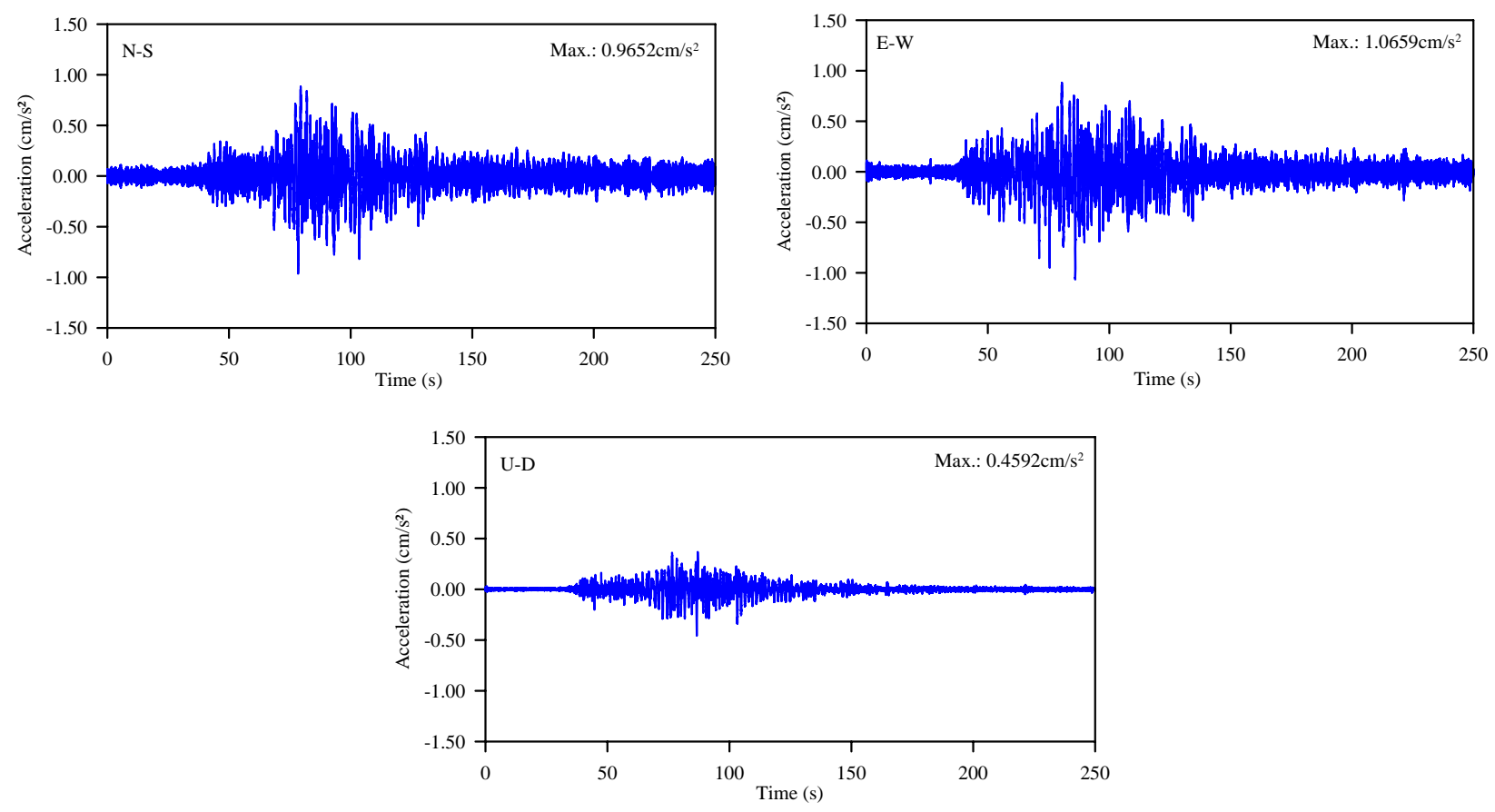

Fig. 4. Acceleration records of Bala (Ankara) Earthquake on 20 December 2007.
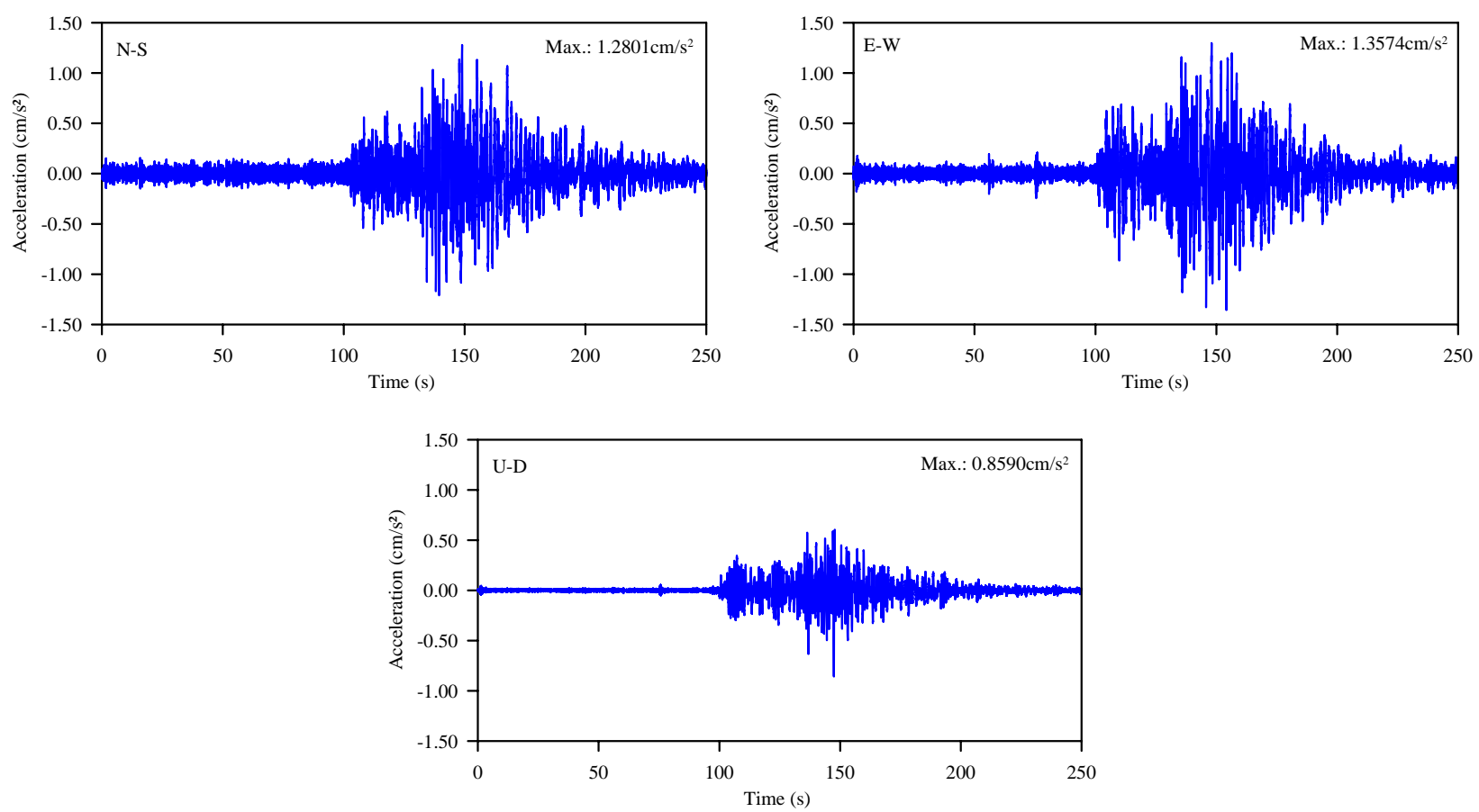

Fig. 5. Acceleration records of Bala (Ankara) Earthquake on 27 December 2007.

This study presents the results of an evaluation of damaged masonry buildings in Bala County and its villages. Masonry buildings were built in three types in the affected area: (1) stone masonry buildings with walls made of natural shaped stones, (2) stone masonry buildings with walls made of cut stones, and (3) mixed masonry buildings with walls made of masonry materials like stones and mud bricks or stones and bricks or stones and briquette. These buildings were commonly constructed by their own residents without any engineering knowledge. Most of the masonry buildings have clay-mud mortar, whereas some have sand-cement mortar. 

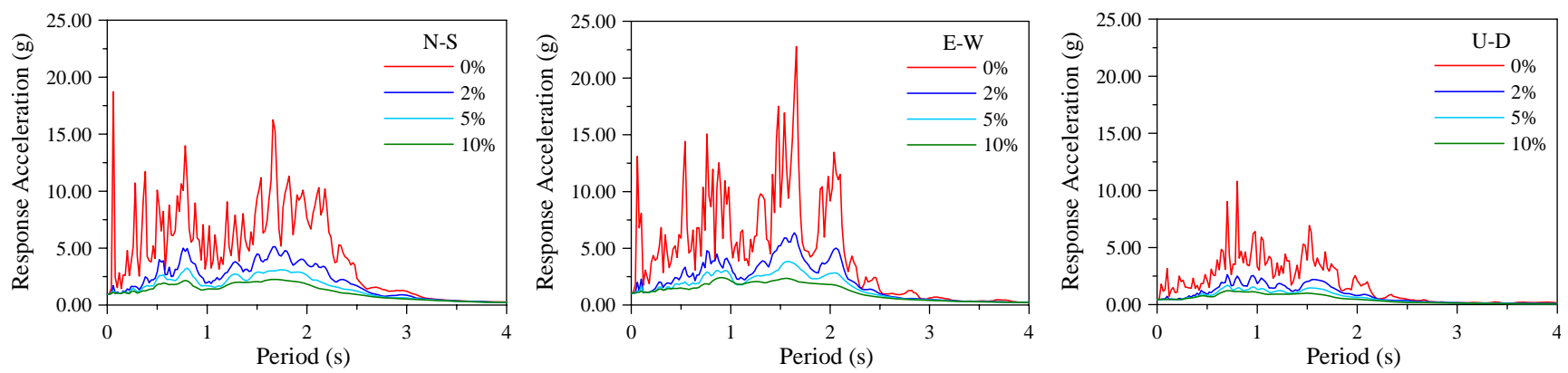

Fig. 6. Response spectrums of Bala (Ankara) Earthquake on 20 December 2007.
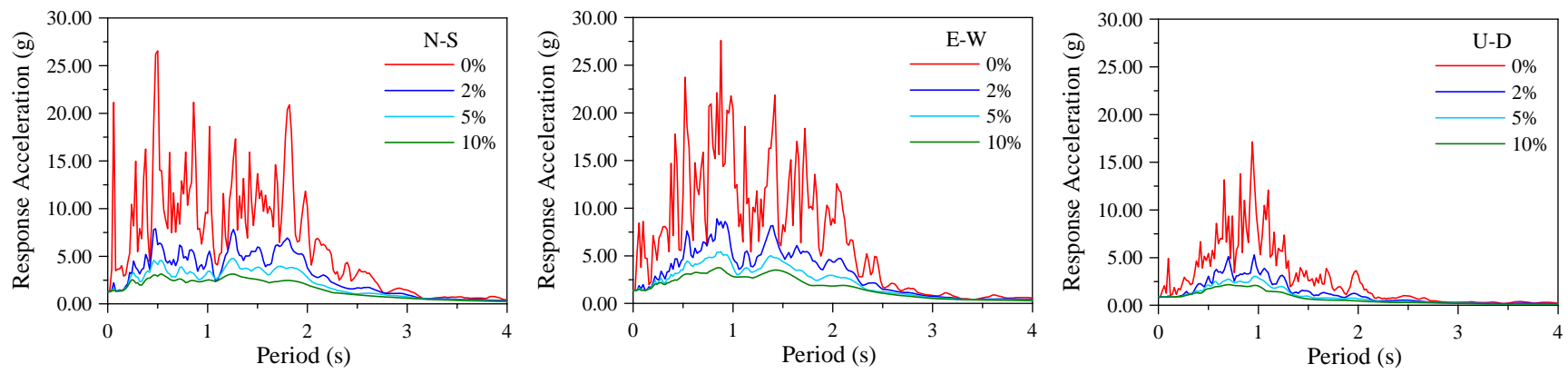

Fig. 7. Response spectrums of Bala (Ankara) Earthquake on 27 December 2007.

\section{Damages to masonry buildings in the affected area}

The 20 and 27 December Bala (Ankara) earthquakes caused significant damage to Bala and its vicinity. The two earthquakes struck the buildings within seven days. A large proportion of the non-engineered masonry buildings completely collapsed or were heavily damaged, as shown in Figs. 8 and 9.

The collapse of the building corners are shown in Fig. 10. The corners were badly fractured and the stones collapsed. The failure pattern may be essentially characterised as out-of-plane failure. This mechanism is due to the lack of connection between orthogonal walls and between walls and floors or roofs. According to the Turkish Earthquake Resistant Design Code (2007), reinforced concrete horizontal bond beams shall be provided at places where slabs are supported by walls, such that they shall be cast monolithically with the slabs. The width of the horizontal bond beams shall be equal to the width of the wall and their height shall not be less than $200 \mathrm{~mm}$. However, horizontal bond beams were not used in the collapsed and damaged masonry buildings observed in the affected area. On the other hand, although there is no information in the Turkish Earthquake Resistant Design Code (2007) about using horizontal wooden bond beams in the stone masonry buildings, it was observed that there were several stone masonry buildings with horizontal wooden bond beams in the affected area, as shown in Fig. 11. There was no damage
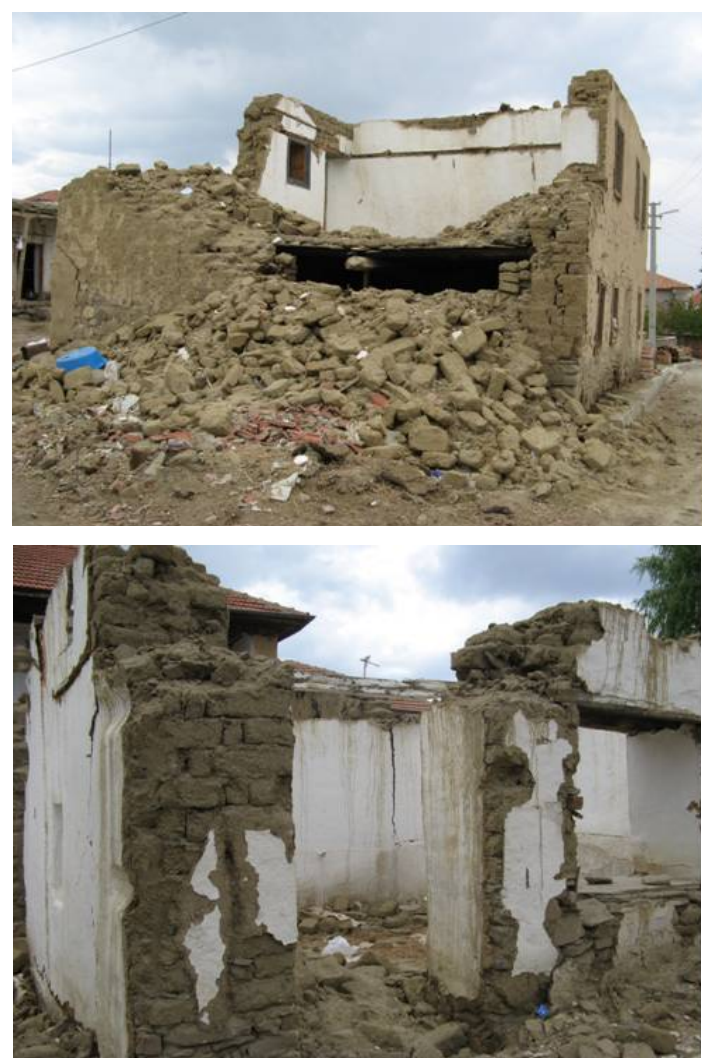

Fig. 8. Examples of completely collapsed masonry buildings. 

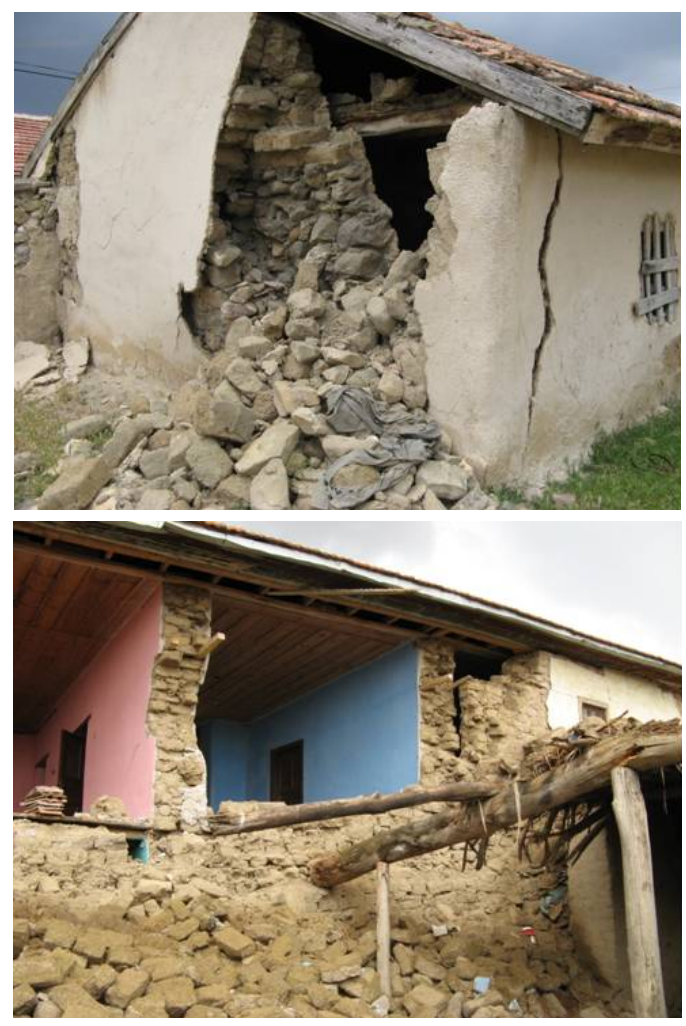

Fig. 9. Examples of heavily damaged masonry buildings.
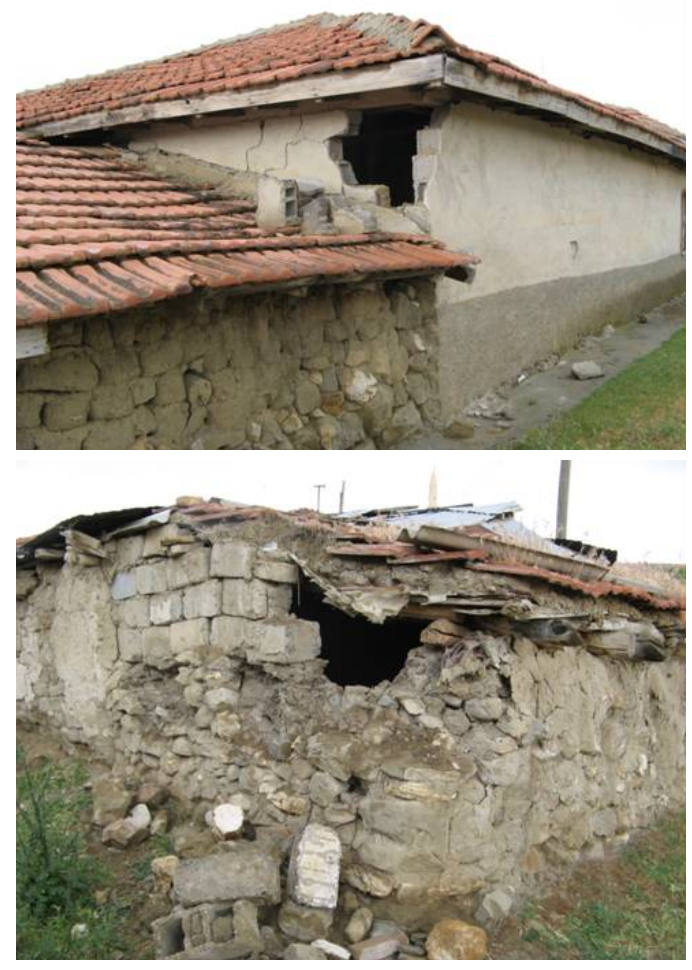

Fig. 10. Examples of failure of masonry building corners.
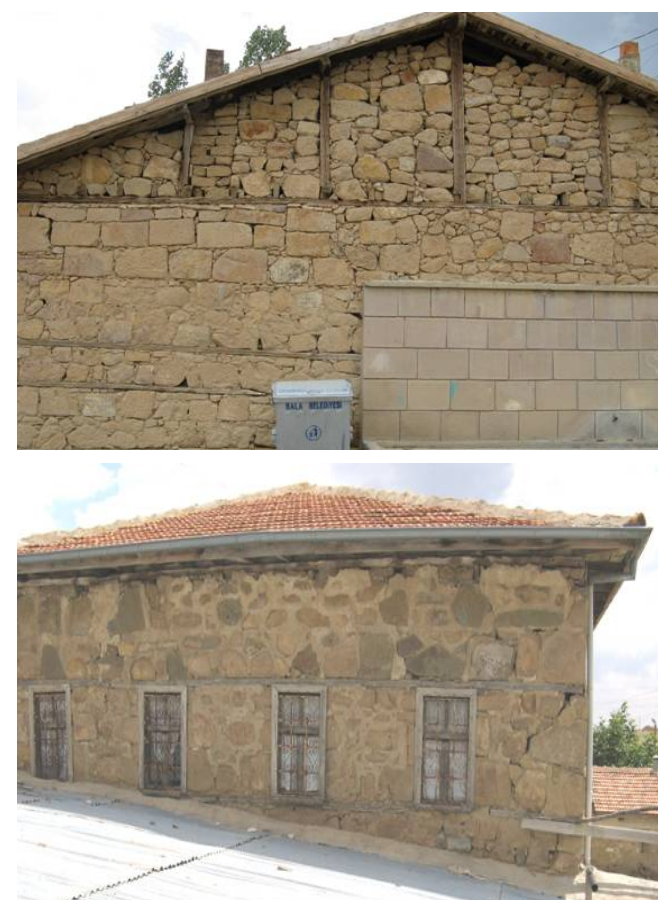

Fig. 11. Examples of masonry buildings formed by horizontal wooden bond beams.

or even low damage in these masonry buildings. Based on this observation, it can be said that horizontal wooden bond beams increase the seismic behaviour of stone masonry buildings.

According to the Turkish Earthquake Resistant Design Code (TERDC, 2007), masonry materials used in the construction of load-bearing walls must be natural stones, solid bricks, bricks with vertical holes, solid concrete briquette, mud bricks, etc. The minimum compressive strength of masonry structural materials must not be less than $5 \mathrm{MPa}$ on the basis of gross compression area. Compression strength of natural stones used in basements must be at least $10 \mathrm{MPa}$. However, some of the masonry buildings in the affected area were formed by low strength stones. One of the most important reasons for the damage is that the stones used in the walls had a low strength (Fig. 12).

Many stone walls were constructed with stones placed in a random manner. These do not have the usual layers (or courses) seen in brick walls. These uncoursed walls have two exterior vertical wythes of large stones, filled in between with loose stone rubble and mud mortar. The cavities within the walls and clayey mud mortar were another source of damage, as shown in Fig. 13.

Load bearing masonry walls act as shear walls to resist inplane lateral loads due to wind or seismic forces. The lateral load carrying capacity of shear wall structures depends mainly on the in-plane resistances of the shear walls, because the in-plane stiffness of a shear wall is far greater than 


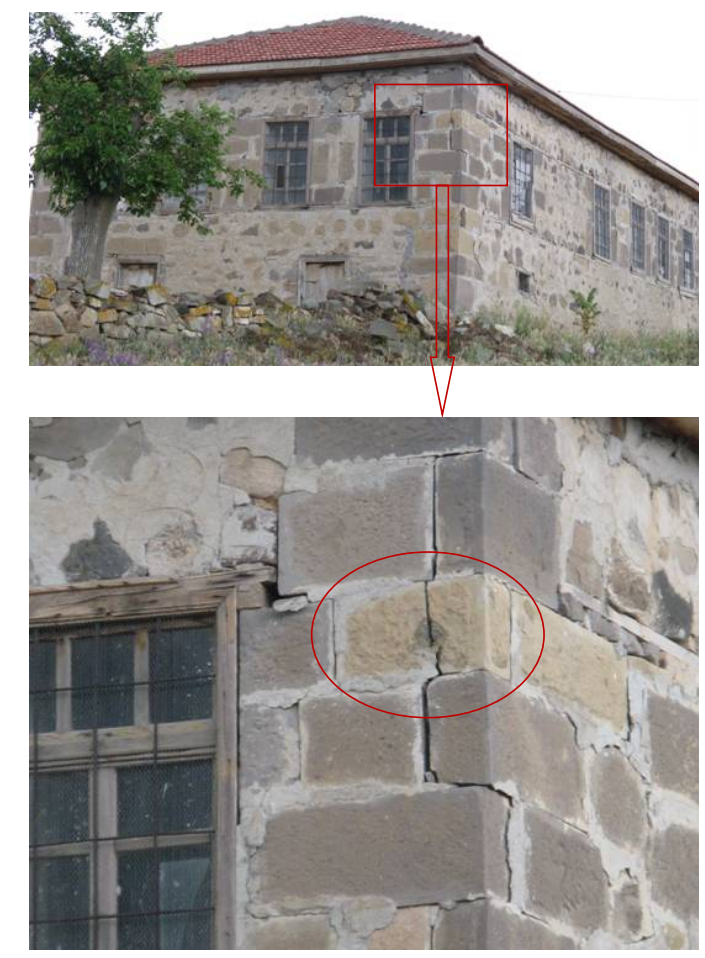

Fig. 12. Example of failure of low strength stone on a masonry building.

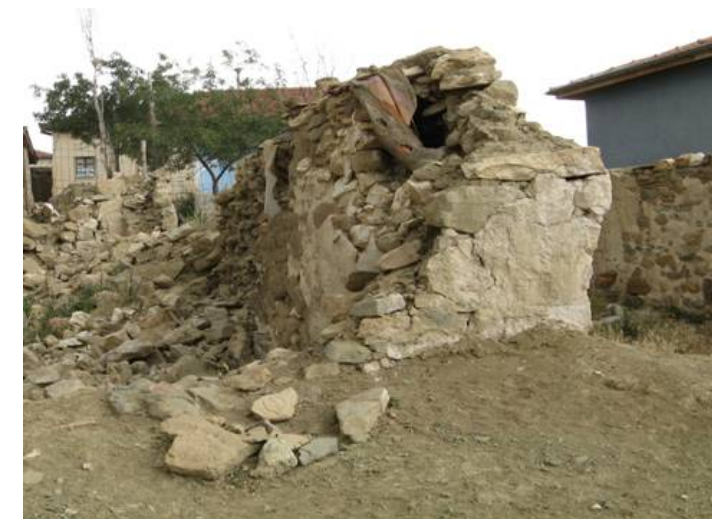

Fig. 13. A masonry wall with cavity and mud mortar.

its out-of plane stiffness. Three modes of shear failure in non-reinforced masonry are: diagonal tension cracks form through the mortar and masonry units; sliding occurs along a straight crack at horizontal bed joints; and stepped cracks form alternatively from head joint to bed joint. Shear cracking on the structural walls was observed in most of the masonry buildings, as shown in Figs. 14-15.

Modes of failure in masonry walls also include out-ofplane failure (swellings) where loads act perpendicular to the wall's face. The out-of-plane failures (swellings) occurred on the structural walls during the earthquakes, as shown in Fig. 16.
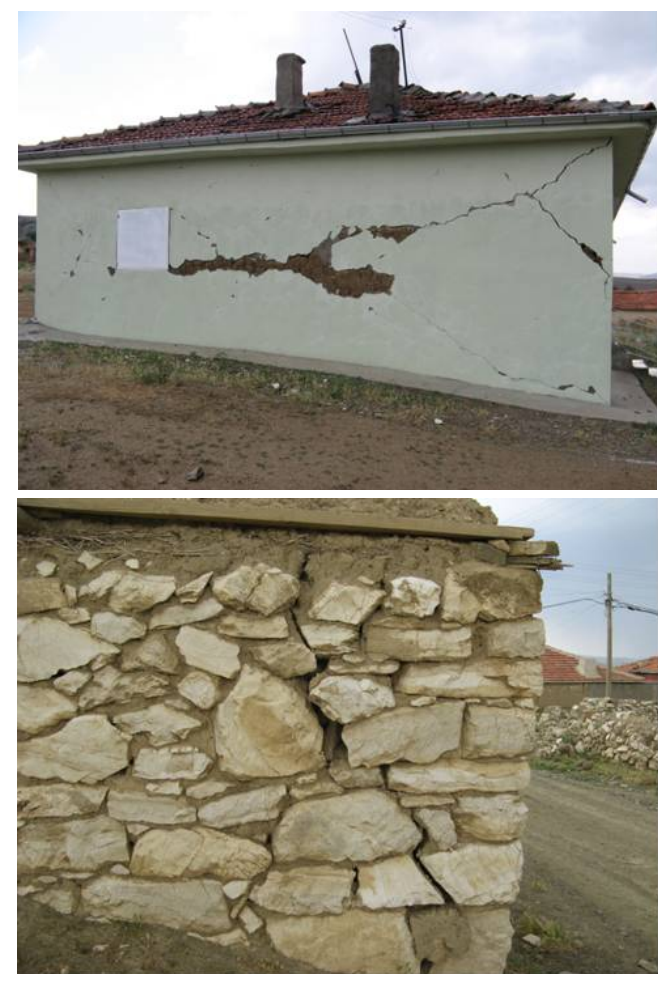

Fig. 14. Examples of diagonal shear cracking on the structural walls.
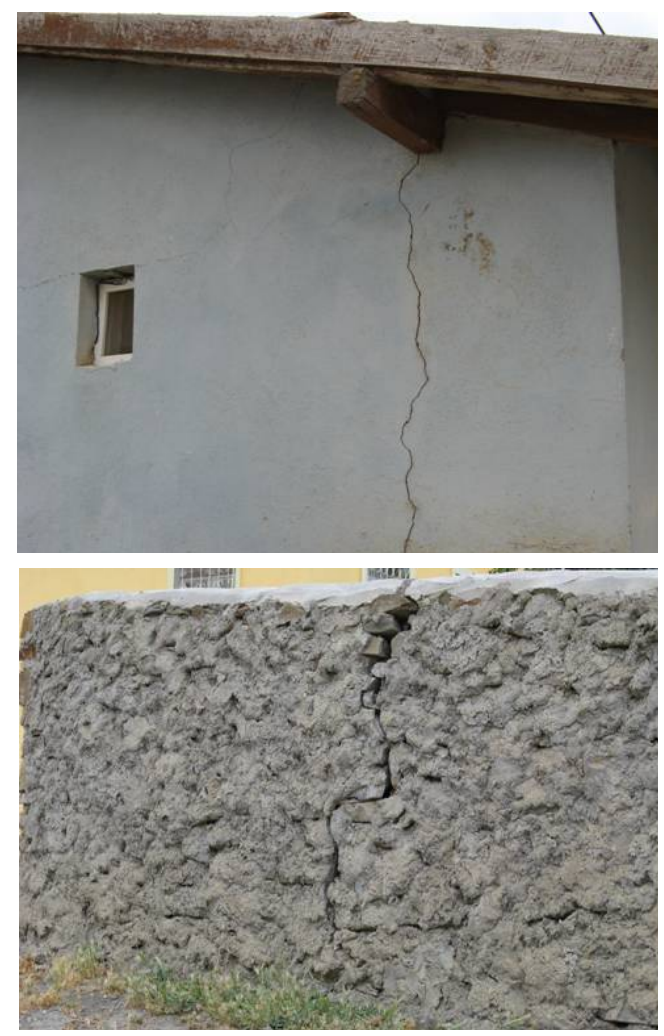

Fig. 15. Examples of shear cracking under vertical shear force on the structural walls. 

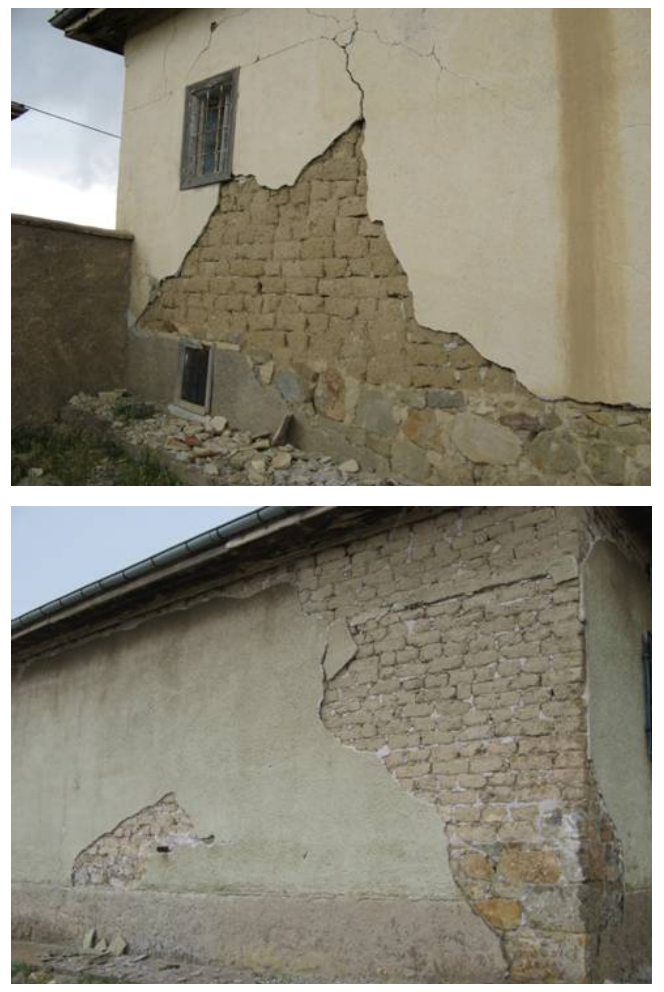

Fig. 16. Examples of out-of-plane failure (swelling) on the structural walls.
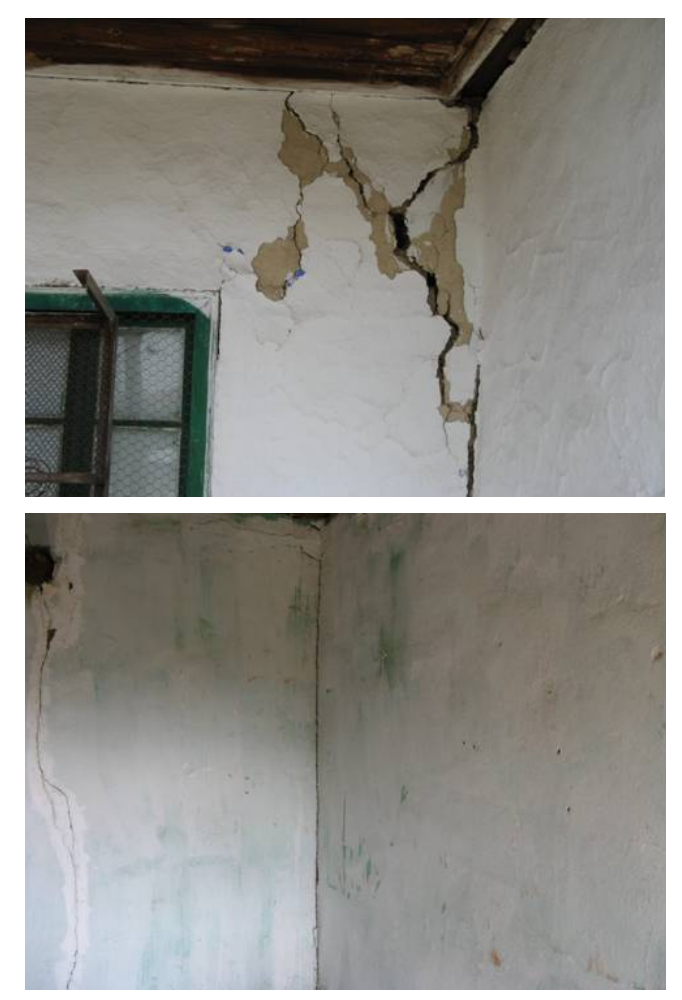

Fig. 17. Examples of openings between the structural walls.
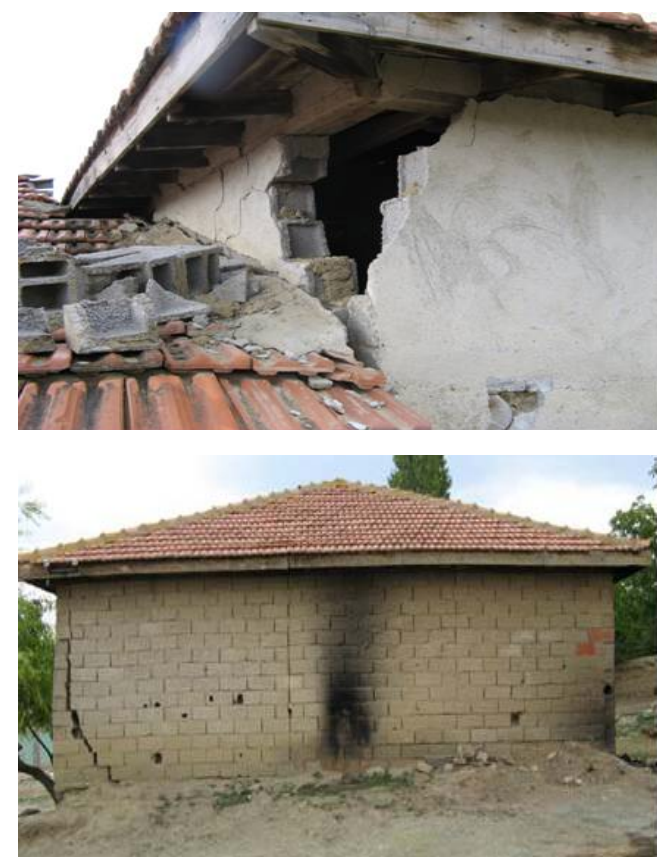

Fig. 18. Examples of masonry buildings formed by concrete briquette with vertical holes or lightweight concrete briquette.

During an earthquake, the lateral loads increase the shear forces in the walls and in the wall-to-wall connection. A lack of connection details was observed in the damaged buildings. It can be seen from Fig. 17 that openings between $5-50 \mathrm{~mm}$ occurred at corners of the structural walls during the earthquakes.

According to Turkish Earthquake Resistant Design Code (2007), concrete briquette with vertical holes or lightweight concrete briquette must not be used in the construction of load-bearing walls of masonry buildings. However, there were several masonry buildings formed by these type concrete briquettes in the affected area. Most of them were damaged during the earthquakes (Fig. 18).

According to Turkish Earthquake Resistant Design Code (2007), height of the fence made of masonry materials shall not be more than $1.0 \mathrm{~m}$. But, there were many damaged fences constructed more than $1.0 \mathrm{~m}$ in height in the affected area, as shown in Fig. 19.

Minarets are tall and slender structures and they are vulnerable to seismic loading. In the Turkish style, the parts of a minaret are the footing as a base; pulpit, transition segment, cylindrical or polygonal body as a shaft; balcony; upper part of minaret body; spire and flag. There was at least one minaret in each village in the affected area. Many of the minarets were constructed using masonry materials like stone and baked clay brick. Several minarets were damaged during the earthquakes, especially its flag and spire as shown in Fig. 20. 

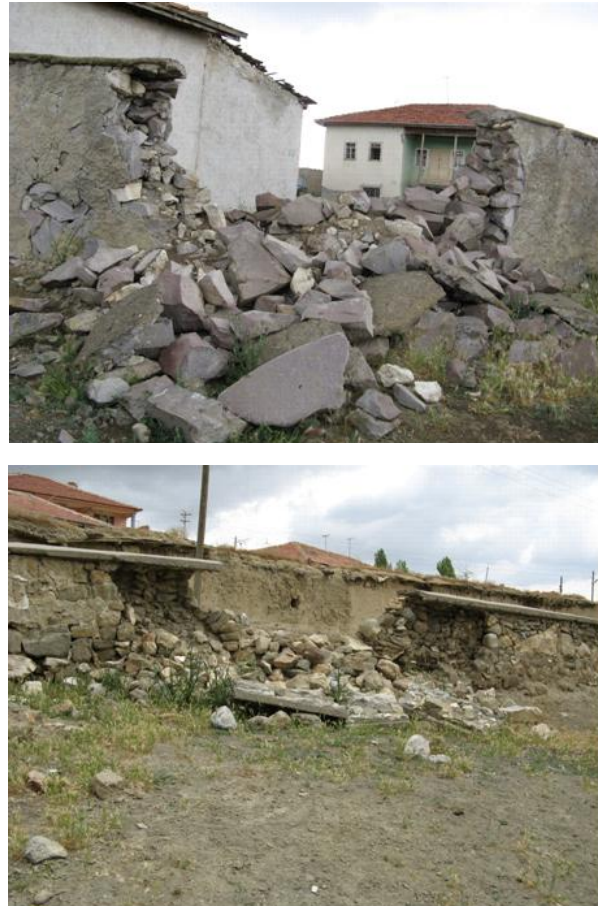

Fig. 19. Examples of damages on the stone masonry fences.
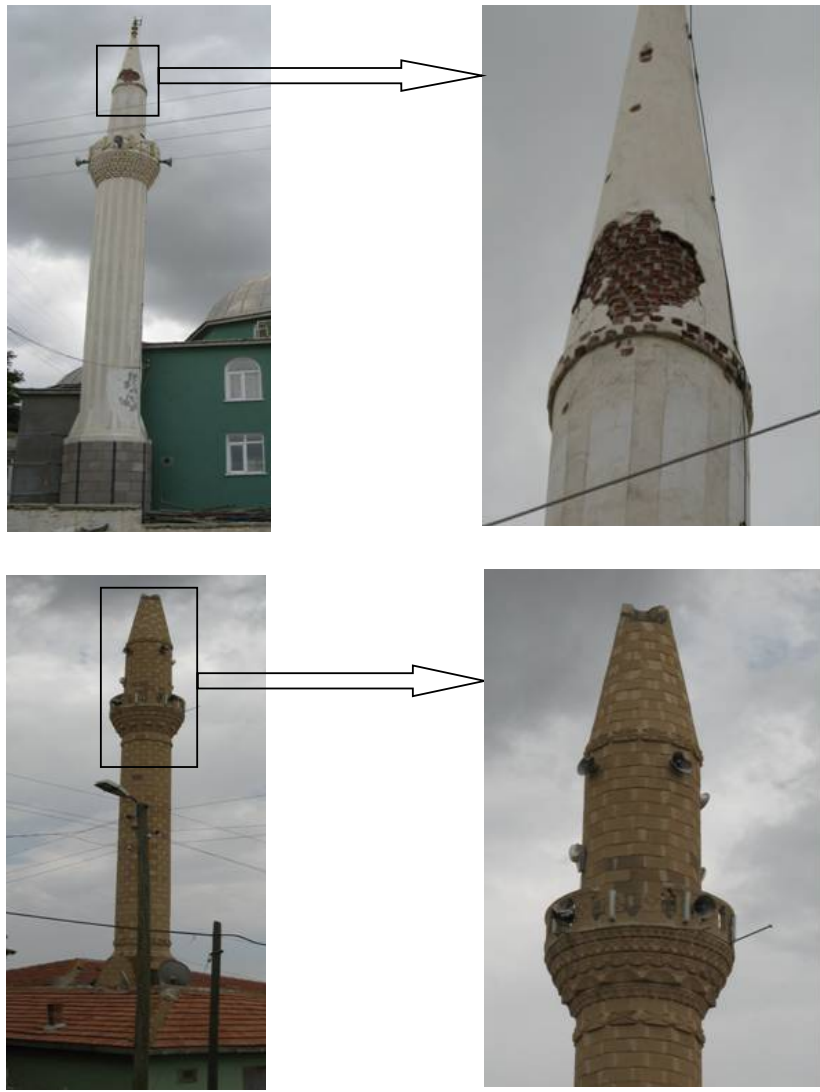

Fig. 20. Examples of damages on the slender masonry buildings.
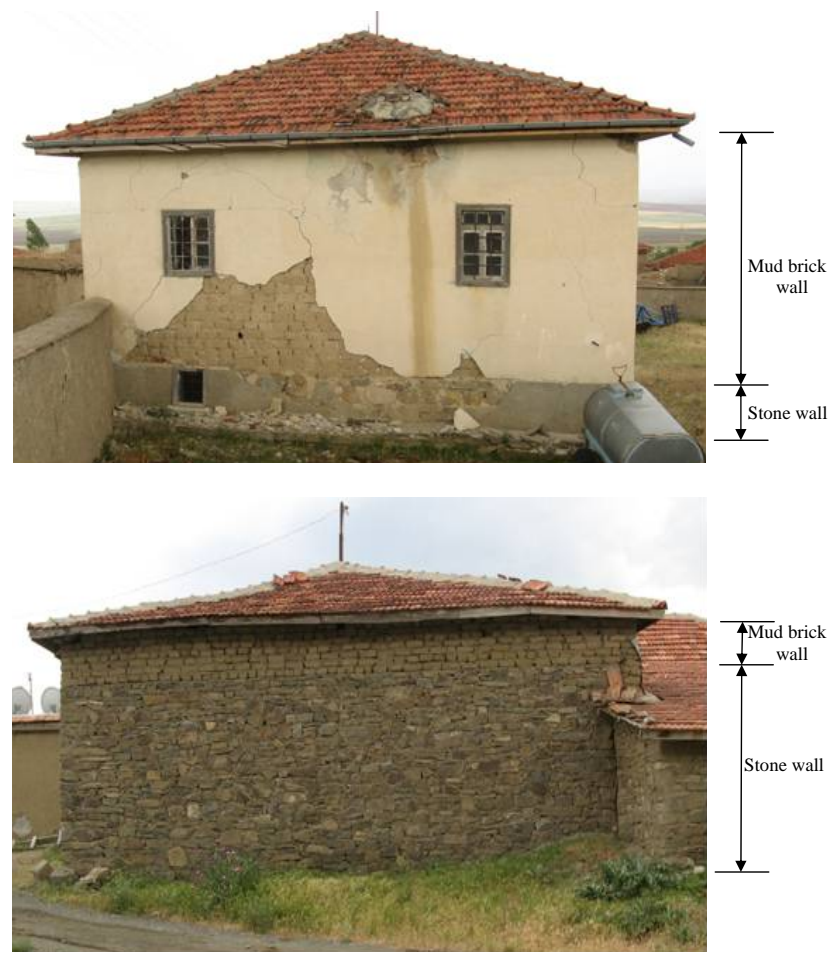

Fig. 21. Examples of mixed type masonry buildings formed by stones and mud bricks.
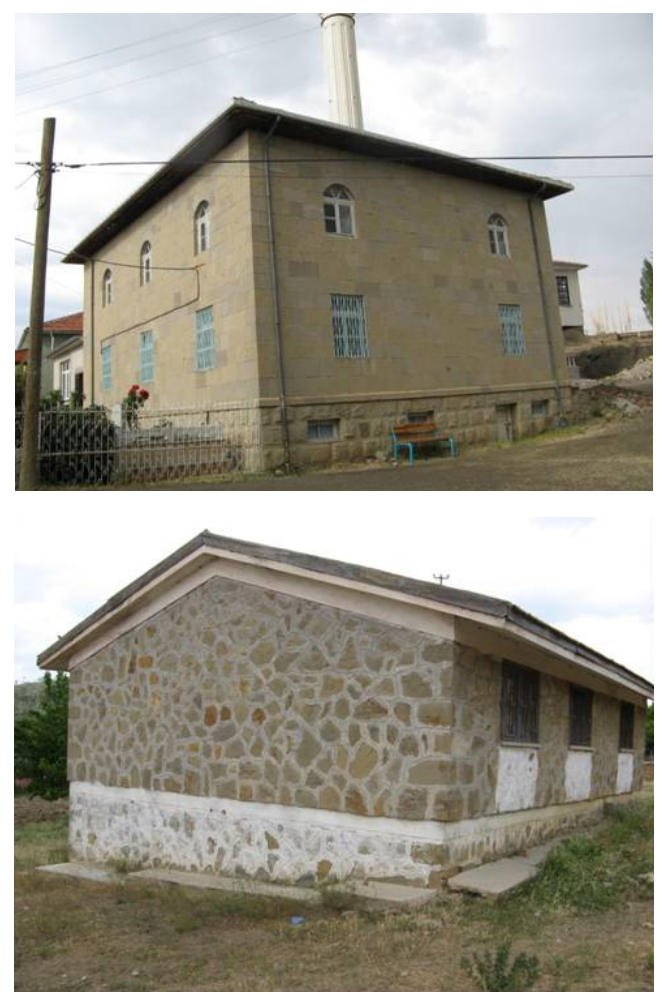

Fig. 22. Examples of undamaged masonry structures. 
Two different mixed type masonry buildings formed by stones and mud bricks are shown in Fig. 21. It can be seen from Fig. 21 that dynamic behaviour of mixed type masonry buildings changed depending on the ratio between the stones to mud bricks. Earthquake resistance of mixed type masonry buildings increased with increasing stone ratio.

Generally, it is seen that the structural performance of the masonry buildings in the affected area was not adequate during the earthquakes. However, there were also some observations of good performance. Some examples are given in Fig. 22. This was mainly due to proper care and good workmanship during the construction.

\section{Conclusions}

The performance of the masonry buildings affected by the 20 and 27 December 2007 medium magnitude ( $M=5.6$ and 5.5) earthquakes in Bala (Ankara) is presented in this paper. Based on the observations of the damages caused to masonry buildings during the earthquakes, the following conclusions could be drawn:

- Most of the masonry buildings in the affected area were not designed and constructed in accordance with Turkish Earthquake Resistant Design Code (2007).

- Low strength stone masonry buildings were weak against earthquakes and should be avoided in high seismic zone.

- Slender masonry buildings like minarets are vulnerable to strong seismic loading and the construction of these type buildings in earthquake areas should be avoided.

- Cavities within the walls decreased the shear strength during the earthquakes.

- Horizontal wooden bond beams used in the construction of stone masonry buildings increased the seismic behaviour of these buildings.

- Mixed type masonry buildings were more affected than stone type masonry buildings during the earthquakes. Also damages on the mixed type masonry buildings increased with the decreasing of the ratio between the stone to the mud brick in the walls.

In addition to these factors, the two earthquakes struck the buildings only seven days apart. Many of the buildings that collapsed in the second earthquake had already been damaged in the first one.

To prevent the catastrophic damages on the masonry buildings to the earthquakes, the buildings satisfy the earthquake code requirements. It is also recommended to avoid building the masonry buildings with walls made of masonry materials like stones and mud bricks or stones and bricks or stones and briquette.
Numerical modelling and experimental studies of the seismic behaviour of masonry structures presents a complex challenge. This study will help establish the need for further research.

Acknowledgements. The author gratefully thanks A. Bayraktar and M. Akköse of the Department of Civil Engineering of Karadeniz Technical University, and Y. Koç; without their invaluable human and scientific supports this research work would have never been possible.

Edited by: M. E. Contadakis

Reviewed by: two anonymous referees

\section{References}

Arslan, M. H. and Korkmaz, H. H.: What is to be learned from damage and failure of reinforced concrete structures during recent earthquakes in Turkey?, Eng. Fail. Anal., 14(1), 1-22, 2007.

Bayraktar, A., Coskun, N., and Yalcin, A.: Performance of masonry stone buildings during the March 25 and 28, 2004 Askale (Erzurum) earthquakes in Turkey, J. Perform. Constr. Fac., 21, 432-440, 2007a.

Bayraktar, A., Coskun, N., and Yalcin, A.: Damages of masonry buildings during the July 2, 2004 Dogubayazit (Agri) earthquake in Turkey, Eng. Fail. Anal., 14(1), 147-157, 2007 b.

Bruneau, M.: Building damage from the Marmara, Turkey earthquake of August 17, 1999, J. Seismol., 6(3), 357-377, 2002.

Dogangun, A.: Performance of reinforced concrete buildings during the May 1, 2003 Bingol Earthquake in Turkey, Eng. Struct., 26(6), 841-856, 2004.

Inel, M., Ozmen, H. B., and Bilgin, H.: Re-evaluation of building damage during recent earthquakes in Turkey, Eng. Struct., 30(2), 412-427, 2008.

Özmen, B. and Kocaefe, S.: The Seismicity and Earthquake Hazard of Ankara, International Workshop on Recent Earthquakes and Disaster Prevention Management, 10-12 March, ODTU, Ankara, 1999.

Saatcioglu, M. and Bruneau, M.: Performance of structures during the 1992 Erzincan earthquake, Can. J. Civil Eng., 20(2), 305325, 1993.

Turkish Earthquake Resistant Design Code (TERDC): Specifications for structures to be built in disaster areas, Ministry of Public Works and Settlement, General Directorate of Disaster Affairs, Earthquake Research Department, Ankara, Turkey, available at: http://www.deprem.gov.tr (last access: 5 September 2010), 2007 (in Turkish).

U.S. Geological Survey (USGS): Preliminary earthquake report, available at: http://neic.usgs.gov/neis/eq_depot/2003/eq_030501/ neic_tgac_maps.html (last access: 7 September 2008), 2008. 